\title{
Genetic Diversity in Spanish and Foreign Almond Germplasm Assessed by Molecular Characterization with Simple Sequence Repeats
}

\author{
Àngel Fernández i Martí, José M. Alonso, María T. Espiau, María J. Rubio-Cabetas, and \\ Rafel Socias i Company ${ }^{1}$ \\ Unidad de Fruticultura, Centro de Investigación y Tecnología Agroalimentaria de Aragón (CITA), \\ Av. Montañana 930, 50059, Zaragoza, Spain
}

\begin{abstract}
Additional Index words. Prunus amygdalus, Prunus dulcis, identification, geographical distribution, similarity, genealogy
Abstract. Genetic diversity of the Spanish national almond (Prunus amygdalus Batsch) collection was characterized with 19 simple sequence repeat (SSR) markers selected because of their polymorphism in almond and other Prunus L. species. A total of 93 almond genotypes, including 63 Spanish cultivars from different growing regions, as well as some international cultivars and breeding releases were analyzed. All primers produced a successful amplification, giving a total of 323 fragments in the genotypes studied, with an average of 17 alleles per SSR, ranging from 4 (EPDCU5100) to 33 (BPPCT038). Allele size ranged from 88 bp at locus PMS40 to $260 \mathrm{bp}$ at locus CPPCT022. The heterozygosity observed (0.72) was much higher not only than in other Prunus species, but also than in other almond pools already studied. The dendrogram generated using the variability observed classified most of the genotypes according to their geographical origin, confirming the particular evolution of different almond ecotypes. The SSR markers have consequently shown their usefulness for cultivar identification in almond, for establishing the genetic closeness among its cultivars, and for establishing genealogical relationships.
\end{abstract}

Almond \{Prunus amygdalus [syn. P. dulcis (Mill.) D.A. Webb] $\}$ is a species in the Rosaceae family with a genome $2 \mathrm{n}=$ 16. The almond is the most important tree nut crop in terms of production and is one of the most polymorphic fruit species (Kester et al., 1991; Socias i Company and Felipe, 1992). This high polymorphism may be due to its self-incompatibility (Socias i Company, 1998) and to the utilization of openpollinated seedlings in traditional almond culture (Grasselly, 1972; Rikhter, 1972). The almond originated in central Asia (Grasselly, 1976) and is probably the oldest tree nut crop to be domesticated, possibly during the third millennium BCE (Spiegel-Roy, 1986). Over several centuries, almond spread from its center or origin toward the Mediterranean Basin, and was introduced by the Phoenicians, Greeks, and Romans into the different Mediterranean regions, expanding from Greece and the Balkans to Spain and Portugal. In all the Mediterranean Basin, both in the northern and southern shores, almond production became concentrated in specific areas, mostly with a traditional cultural system, adapted to the drought-resistant and frost-sensitive characteristics of the available almond germplasm, resulting as a consequence in the emergence of adapted land races associated with specific production areas (Grasselly and Crossa-Raynaud, 1980). Although seedling propagation resulted in the proliferation of a large number of

\footnotetext{
Received for publication 24 July 2009. Accepted for publication 8 Sept. 2009. This research was funded by the grants INIA-RF2008-00027, CICYT AGL2007-65853-C02-02, AGRI GEN RES 870/2004 068 (SAFENUT), and the Research Group A12 of Aragón. A. Fernández i Martí acknowledges a scholarship cofunded by the Spanish 'Ministerio de Educación y Ciencia' and the European Social Fund (FSE), under projects AGL 2004-06674-C02-01 and BES-2006-12621.

Helpful comments by P. Arús, W. Howad and E. Collell (IRTA-Cabrils) are highly appreciated. We recognize the magnificent task of Dr. Antonio J. Felipe in assembling the Spanish almond germplasm collection.

${ }^{1}$ Corresponding author. E-mail: rsocias@aragon.es.
}

highly variable local genotypes, their origin from a restricted germplasm often limited their genetic diversity, as shown in most islands of the Mediterranean Sea. Thus, the Mediterranean area is considered as a secondary source of domestication for almond (Felipe, 2000; Kester et al., 1991).

The Centro de Investigación y Tecnología Agroalimentaria de Aragón (CITA) almond collection (Espiau et al., 2002) was established in the late 1960s by A.J. Felipe, first by gathering cultivars produced by the Spanish nurseries. At that time, the number of nurseries was important and most of them produced a very high number of cultivars, thus allowing a significant number of accessions to be included. At the same time, a continuous collection effort was undertaken, with expeditions into most of the Spanish growing regions, paying particular attention to such geographically isolated areas as the Balearic and the Canary Islands. Furthermore, an interchange of plant material was maintained with different research centers of all almond-producing regions, allowing the introduction of a large number of foreign cultivars, both traditional and releases from the breeding programs. Especially significant was the number of accessions provided by C. Grasselly from Institut National de la Recherche Agronomique (INRA) in France. As a result of all these introductions, the CITA almond collection shows a very large variability, reflecting the wide genetic diversity of its accessions from all over the world (Socias i Company and Felipe, 1992). Taking this variability into account, this collection was designed as a reference for the Group de Recherches et d'Études Méditerranéen pour l'Amandier (GREMPA), being also the almond reference collection for the Spanish Plant Genetic Resources Network and for the Spanish and the European Plant Variety Offices. This collection was the initial basis for almond studies in Spain, including breeding, pollen compatibility, cultivar description (Felipe, 2002), chilling and heat requirements (Alonso et al., 2005), and $S$-genotype identification (Kodad et al., 2008). 
Genetic diversity has been traditionally assessed by phenotypic observations, mainly based in the International Board for Plant Genetic Resources [IBPGR (now Bioversity International)] descriptors (Gülcan, 1985). However, the usually long juvenile period and the large size of the fruit trees, as well as the influence of the environment create many difficulties for the proper classification of the plant material exclusively by morphological traits. Thus, molecular identification using DNA markers has become the main tool for the characterization and management of the germplasm collections of most fruit species. For the Prunus genus, such studies were first carried out using isozymes, such as in peach (Prunus persica L.) (Messeguer et al., 1987) and almond (Cerezo et al., 1989; Hauagge et al., 1987). Later, DNA markers were introduced for cultivar identification, such as restriction fragment length polymorphisms (RFLPs) in apricot [Prunus armeniaca L. (de Vicente et al., 1998)]. Random amplified polymorphic DNA (RAPD) has also been widely used for fingerprinting Prunus species, such as peach (Warburton and Bliss, 1996) and almond (Bartolozzi et al., 1998). More recently, other types of DNA markers combining RFLP and PCR techniques, the amplified fragment length polymorphisms (AFLPs), have been used in the identification of some apricot cultivars (Hurtado et al., 2002). However, SSR (microsatellites or SSRs) are the preferred technique for the study of genetic relationship among species and for the assessment of genetic diversity within crop species (Gupta et al., 1996), due to their high polymorphism, abundance, and codominant inheritance. In Prunus, most SSRs used for fingerprinting have been developed in peach and sweet cherry (Prunus avium L.) (Cipriani et al., 1999; Clarke and Tobutt, 2003; Downey and Iezzoni, 2000; Testolin et al., 2000) and have been successfully used for molecular characterization and genetic similarity of genotypes in several Prunus species, including peach (Aranzana et al., 2002; Dirlewanger et al., 2002). More recently, single nucleotide polymorphism (SNP) markers have also been specifically applied for almond identification (Wu et al., 2008).

Thus far, two studies have applied SSR analysis for cultivar characterization in almond. Martínez-Gómez et al. (2003) analyzed several Californian almond cultivars, concluding that most of them derived from the two most important historical Californian cultivars, Nonpareil and Mission. Xie et al. (2006) studied some Chinese and foreign cultivars, reporting a clear different grouping of cultivars according to their geographic origin, the Chinese and the foreign ones. However, these studies have only included a small set of cultivars, representing a reduced range of the wide variability of almond germplasm. As a consequence, our aim was to identify, by using SSR markers, the most representative accessions from the different Spanish regions included in the CITA almond collection in comparison with other cultivars to establish the genetic relatedness among cultivars.

\section{Material and Methods}

Plant material and DNA extraction. The list of the 93 almond cultivars studied is shown in Table 1 . They were selected among the whole almond pool to have the most representative Spanish local accessions, including 63 genotypes from all the Spanish growing regions. In addition, cultivars from different breeding programs and some foreign cultivars were included as references. The trees are maintained as living plants grafted on the almond $\times$ peach hybrid clonal rootstock INRA GF-677, using standard management practices (Espiau et al., 2002).

Genomic DNA was isolated following the CTAB extraction method based on Doyle and Doyle (1987). The DNA was quantified and diluted to $10 \mathrm{ng} \cdot \mu \mathrm{L}^{-1}$ to carry out PCR amplifications.

SSR AMPLIFICATION. Nineteen SSR markers previously developed in peach, plum (Prunus salicina Lindl.), sweet cherry, and almond (Table 2) were used. These primers were selected because of their polymorphism in these species and because they are distributed among the eight Prunus linkage groups (P. Arús, unpublished data), thus representing wide coverage of the almond genome. PCR reactions were performed in a $20-\mu \mathrm{L}$ volume and the reaction mixture contained $1 \times$ PCR buffer (Invitrogen, Barcelona, Spain), $1.5 \mathrm{~mm} \mathrm{MgCl}_{2}, 0.2 \mathrm{~mm}$ dNTPs, $0.2 \mu \mathrm{M}$ of each primer, one unit of Taq DNA Polymerase (Invitrogen), and $20 \mathrm{ng}$ of genomic DNA. The cycling parameters consisted in a denaturation during $1 \mathrm{~min}$ at $94{ }^{\circ} \mathrm{C}, 35$ cycles of $15 \mathrm{~s}$ at $94{ }^{\circ} \mathrm{C}, 15 \mathrm{~s}$ for the annealing temperatures indicated in Table 2 for the different primers used, and $1 \mathrm{~min}$ at $72{ }^{\circ} \mathrm{C}$, followed by a final extension of $2 \mathrm{~min}$ at $72^{\circ} \mathrm{C}$. The PCR reactions were carried out in a 96-well block Thermal cycler (Applied Biosystems, Madrid, Spain). PCR products were detected using an ABI PRISM 3130 Genetic Analyzer and GeneMapper analysis software (Applied Biosystems). Each reaction was repeated and analyzed twice for confirmation. For capillary electrophoresis detection, forward SSR primers were labeled with 5' -fluorescence dyes PET, NED, VIC, and 6-FAM and the size standard used in the sequencer was Gene $\mathrm{Scan}^{\mathrm{TM}}$ 500 Liz $^{\circledR}$ (Applied Biosystems).

Data ANALYSIS. The information obtained with the 19 SSRs allowed the calculation of several parameters for diversity analysis: the number of alleles per locus $(\mathrm{N})$, the effective number of alleles detected per locus $\left(\mathrm{N}_{\mathrm{e}}\right)$, the observed heterozygosity $\left(\mathrm{H}_{\mathrm{o}}=\right.$ number of heterozygous individuals/ number of individuals scored), the expected heterozygosity $\left(H_{e}=1-\sum \rho_{i}{ }^{2}\right.$, were $\rho_{i}$ is the frequency of the $i^{\text {th }}$ allele $)$, and the Wright's fixation index $\left(\mathrm{F}=1-\mathrm{H}_{\mathrm{o}} / \mathrm{H}_{\mathrm{e}}\right)$ for comparing both heterozygosities (Wright, 1951). Genetic relationships among genotypes were estimated using the unweighted pair group method average (UPGMA) cluster analysis. The genetic distance between cultivars was obtained with NTSYSpc-2.11 (Exeter Software, Stauket, NY). A dendrogram was generated using the UPGMA based on the Nei and Li (1979) similarity index.

\section{Results and Discussion}

Microsatellite POLYMORPHiSM AND HETEROZYGoSity. Amplification of the 19 SSRs initially developed in three other Prunus species and almond was successful in the 93 almond genotypes studied. These primer pairs produced a total of 323 alleles ranging from 4 to 33 per locus. All primer pairs but three produced a maximum of two bands per genotype in accordance with the diploid level of this species, whereas ВРРСТ033, UDP96-005, and CPPCT033 were able to amplify two different loci in some cultivars (Table 2). Genotypes showing a single band were considered homozygous for that particular locus. The mean value found was 17.2 alleles per locus, which is much higher than the 4.7 value obtained by Martínez-Gómez et al. (2003) and the 6.3 average reported by Xie et al. (2006). 
Table 1. Almond genotypes analyzed for characterization with SSRs.

\begin{tabular}{|c|c|c|c|c|}
\hline Country of origin & Region $^{z}$ & Cultivar & Pedigree & Clone No. \\
\hline \multirow[t]{46}{*}{ Spain } & NE (Huesca) & Abizanda & Unknown & 526 \\
\hline & & AS-1 & Unknown & 80 \\
\hline & & Castilla & Unknown & 52 \\
\hline & & Trell & Unknown & 7 \\
\hline & NE (Zaragoza) & Bertina & Unknown & 448 \\
\hline & & Bulbuente & Unknown & 549 \\
\hline & NE (Huesca-Lleida) & Desmayo Largueta & Unknown & 366 \\
\hline & NE (Huesca-Zaragoza) & Desmayo Rojo & Unknown & 154 \\
\hline & NE (Lleida) & Les Garrigues & Unknown & 136 \\
\hline & & M. Arbeca & Unknown & 525 \\
\hline & & Pané-Barquets & Unknown & 217 \\
\hline & & Planeta de les Garrigues & Unknown & 218 \\
\hline & Central (Cuenca) & Aspirilla & Unknown & 547 \\
\hline & SE (Murcia) & Atocha & Unknown & 288 \\
\hline & & Colorada & Unknown & 362 \\
\hline & & Garrigues & Unknown & 269 \\
\hline & & Peraleja & Unknown & 3 \\
\hline & & Ramillete & Unknown & 287 \\
\hline & SE (Alicante) & Coop. Mañán & Unknown & 550 \\
\hline & & Marcona & Unknown & 190 \\
\hline & & Pestañeta & Unknown & 306 \\
\hline & & Pestañeta menuda & Unknown & 267 \\
\hline & & Rumbeta & Unknown & 423 \\
\hline & & Jordi & Unknown & 244 \\
\hline & & Menut & Unknown & 247 \\
\hline & & $\mathrm{Pau}$ & Unknown & 234 \\
\hline & & Ponç & Unknown & 246 \\
\hline & & Pou d'Establiments & Unknown & 243 \\
\hline & & Pou de Felanitx & Unknown & 237 \\
\hline & & Taiatona & Unknown & 242 \\
\hline & & Totsol & Unknown & 240 \\
\hline & & Verdereta & Unknown & 239 \\
\hline & & Vinagrilla & Unknown & 245 \\
\hline & & Vivot & Unknown & 241 \\
\hline & & Xina & Unknown & 236 \\
\hline & Tenerife, Canary Islands & Arguayo 1 & Unknown & 374 \\
\hline & & Arguayo 2 & Unknown & 378 \\
\hline & Palma, Canary Islands & Castañera & Unknown & 368 \\
\hline & & Colorada de Canarias & Unknown & 370 \\
\hline & & Dura de Tijarafe & Unknown & 369 \\
\hline & & El Paso 4 & Unknown & 375 \\
\hline & & Liso & Unknown & 372 \\
\hline & & Padre Santo & Unknown & 377 \\
\hline & & Redonda de Palma & Unknown & 371 \\
\hline & & Tejeda 1 & Unknown & 376 \\
\hline & & Tejeda 2 & Unknown & 373 \\
\hline
\end{tabular}


Table 1. Continued.

\begin{tabular}{|c|c|c|c|c|}
\hline Country of origin & Region $^{z}$ & Cultivar & Pedigree & Clone No. \\
\hline \multirow[t]{2}{*}{ France } & & Aï & Unknown & 89 \\
\hline & & Belle d'Aurons & Aï OP & 339 \\
\hline \multirow[t]{3}{*}{ Italy } & Sicily & Avola & Unknown & 173 \\
\hline & Apulia & Fragiulio & Unknown & 333 \\
\hline & & Genco & Unknown & 257 \\
\hline \multirow[t]{2}{*}{ Tunisia } & & Achaak & Unknown & 506 \\
\hline & & Zahaf & Unknown & 324 \\
\hline Algeria & & Constantini & Unknown & 176 \\
\hline United States & California & Tardy Nonpareil & Budsport of Nonpareil & 524 \\
\hline Argentina & & Marcona Argentina & Unknown & 447 \\
\hline Australia & South Australia & Chellastone & Unknown & 260 \\
\hline & & Blanquerna & Genco OP & 434 \\
\hline & & Cambra & Tuono $\times$ Ferragnès & 398 \\
\hline & & Felisia & Titan $\times$ Tuono & 427 \\
\hline & & Garfi & Garrigues OP & 484 \\
\hline & & Guara & Unknown & 387 \\
\hline & & Mardía & Felisia $\times$ Bertina & 541 \\
\hline & & Moncayo & Tardive de la Verdière $\times$ Tuono & 399 \\
\hline & & Soleta & Blanquerna $\times$ Belle d'Aurons & 503 \\
\hline & IRTA & Glorieta & Primorskij $\times$ Cristomorto & 494 \\
\hline & & Masbovera & Primorskiy $\times$ Cristomorto & 491 \\
\hline & & Tarragonès & Cristomorto $\times$ Primorskij & 493 \\
\hline
\end{tabular}

${ }^{\mathrm{z}} \mathrm{NE}=$ northeast, $\mathrm{SE}=$ southeast, $\mathrm{SW}=$ southwest.

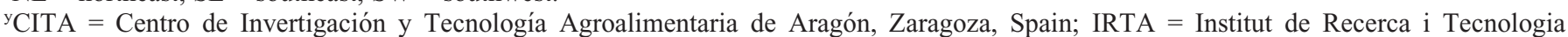
Agroalimentària, Spain; CEBAS = Centro de Esdafología y Bología Aplicada del Segura, Murcia, Spain; INRA = Intitut National de la Recherche Agronomique, France; ISF = Istituto Sperimentale per la Frutticoltura, Rome.

Microsatellite BPPCT038 detected the highest number of alleles (33) among the 93 genotypes analyzed, followed by CPPCT006 with 23 different alleles. EPDCU5100 detected the lowest number of alleles, only four. Amplification with the other 17 SSRs was variable, ranging between 12 and 22 (Table 2). Allele size varied from $88 \mathrm{bp}$ at locus PMS40 to $260 \mathrm{bp}$ at locus CPPCT022 (Table 2). Observed heterozygosity ranged between 0.24 for EPDCU5100 and 0.94 for CPPCT006, with an average of 0.72 across the 16 SSRs. To avoid possible deviations in the data analysis, the three markers that amplified more than one locus were not included for calculation of the observed heterozygosity and the fixation index. The average heterozygosity value of 0.72 is only slightly higher than that observed in the Chinese cultivars (0.69) by Xie et al. (2006), but much higher than the 0.59 value reported by Martínez-Gómez et al. (2003). Only for a single primer, ВРPCT007, was it possible to compare the heterozygosity between different studies, with a value of 0.79 in Xie et al. (2006), nearly identical to 0.77 in our study. The higher values obtained for the number of alleles per locus and for heterozygosity confirmed the wider genetic diversity shown by the CITA almond collection (Socias i Company and Felipe, 1992) in comparison with the genotypes previously studied, as well as the higher number of genotypes included. These higher values may also be due to the higher resolution of the capillary electrophoresis for efficient separation of close alleles in comparison with the nonautomated techniques.

Expected and observed heterozygosity values were compared with the fixation index $(F)$, which was on the average 0.13 , ranging between -0.03 (CPDCT045) and 0.47 (CPSCT018). High F values in combination with individuals in homozygosis (or showing only one band) for these primers suggest the presence of a null allele (Brookfield, 1996). It was positive in 13 primers, whereas it was negative in the others (CPDCT045, EPPCU3083, and CPPCT006), indicating a high level of heterozygosis in the genotypes analyzed, as it would 
Table 2. SSR loci from different Prunus species analyzed in the almond cultivars studied, linkage group of their localization, number of alleles obtained, their size range, observed (Ho) and expected $(\mathrm{He})$ heterozygosities, fixation index $(\mathrm{F})$, and genetic distance $(\mathrm{Ne})$.

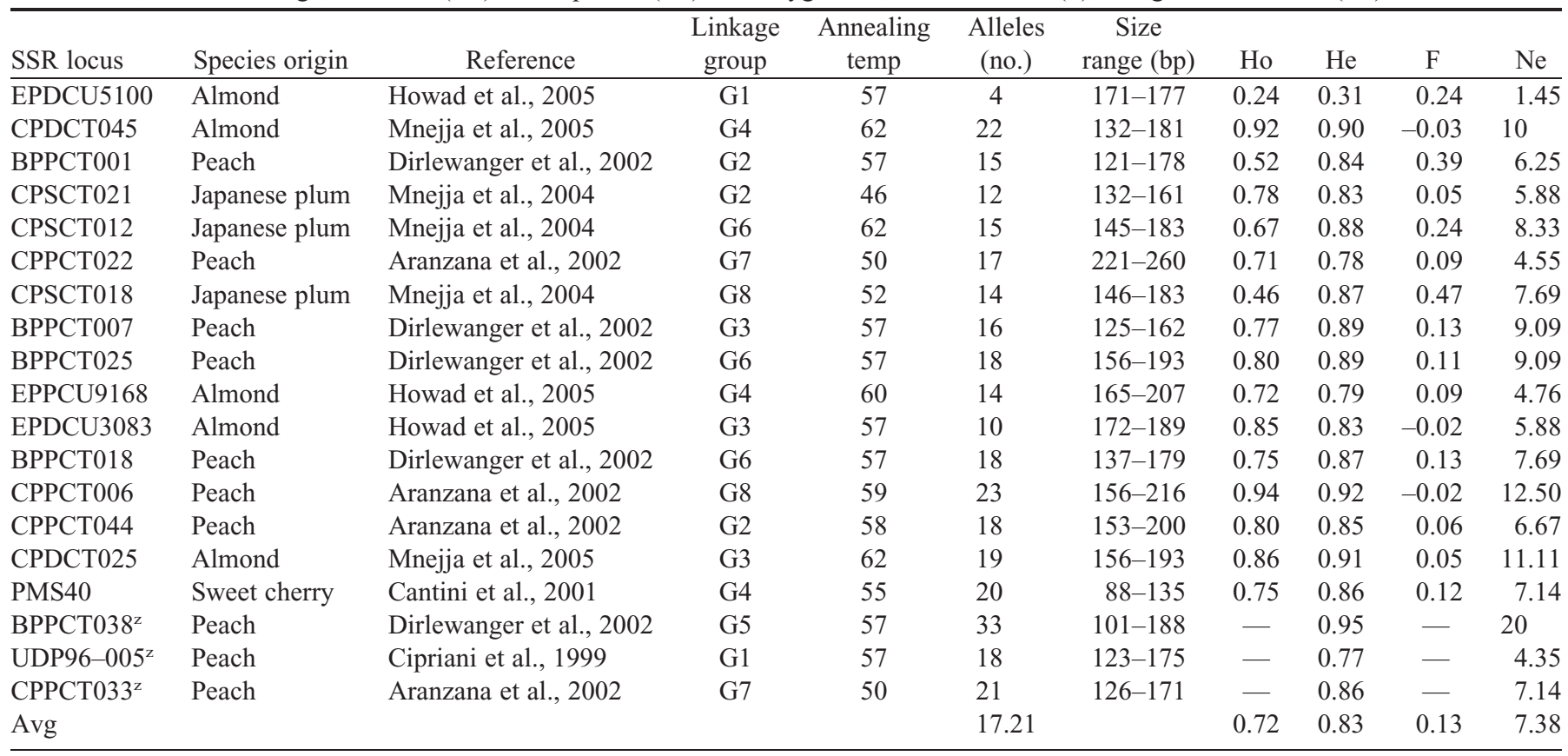

${ }^{\mathrm{z}}$ Multiloci SSRs in some of the plants analyzed and excluded from the calculations.

be expected in a self-incompatible species such as almond. No differences between the heterozygosity levels of self-compatible and self-incompatible cultivars were observed, as it would be expected considering that self-compatible cultivars are heterozygous for self-compatibility (Socias i Company, 1990). The high number of alleles obtained with these primers indicates that the SSR primers developed in other Prunus species can be effectively used for fingerprinting in almond, thus providing very useful information for plant breeding programs and management of genetic resources. In addition, the successful utilization of these SSR markers in the other species of Prunus shows the high level of synteny within this genus (Aranzana et al., 2003; Arús et al., 2006).

The high level of heterozygosity observed in this set of almond genotypes agrees with the results already mentioned in comparison with other species, mainly with peach, the closest Prunus species to almond. This higher level of heterozygosity has also been described with other markers such as enzymes (Arulsekar et al., 1986).

Genetic RELATIONSHIPS AMONG GENOTYPES. Most cultivars studied in this work have not been previously analyzed for molecular characterization, but the results allow confirmation that the geographical diversity of the accessions of the CITA germplasm collection is also reflected in their genetic diversity. This diversity is not only observed between the Spanish accessions and the foreign cultivars, as reported by Xie et al. (2006) when distinguishing the Chinese and the foreign accessions, but also for the different Spanish genotypes. This genetic diversity supports the previous observation that the CITA collection represents a very comprehensive collection of the almond genetic pool, not only by the number of accessions, but also because of the variability contributed by the different accessions (Socias i Company and Felipe, 1992).

When the dendrogram of the 93 almond cultivars was drawn based on the UPGMA cluster analysis, the genotypes were classified into five groups of different size (Fig. 1), further subdivided depending on the cluster proximity of the accessions. For some of these groups, a close relationship with their geographical origin could be established. Thus, the first group only included the three cultivars representing the north African accessions of our analysis, Zahaf, Constantini, and Achaak. In spite of their common geographical origin, the genetic distance between them is significant, with similarity coefficients lower than 0.34. Although 'Zahaf' and 'Achaak' belong to the very well-defined group of Tunisian cultivars from Sfax (Grasselly and Crossa-Raynaud, 1980), 'Zahaf' is closer to the Algerian 'Constantini' than to 'Achaak'.

The second group includes most of the Spanish cultivars, but excludes most of those coming from the Canary Islands. This group appears to be the most diversified, allowing it to be subdivided into three subgroups. The first subgroup comprises only cultivars from southeastern Spain (Alicante, Murcia, and Albacete provinces), with representative cultivars such as Marcona, Pestañeta, Pestañeta menuda, Tendra Amarga, Rumbeta, Elvira, Colorada, Cooperativa Mañán, Atocha, and Del Cid. The second subgroup contains only cultivars from northeastern Spain (Aragón and Catalonia regions), such as Desmayo Largueta, M. Arbeca, Pané-Barquets, Abizanda, Biota, Bulbuente, Tardaneta, Castilla, Desmayo Rojo, Rof, and AS-1, but also Arguayo-2 from the Canary Islands, although this is a case of synonymy with Desmayo Largueta. The third subgroup can be divided into two clusters. The first cluster only contains cultivars from the island of Majorca (Menut, Totsol, Taiatona, Pau, Verdereta, Vivot, Vinagrilla, Pou dEstabliments, and Xina) and Ramillete, from southeastern Spain. The second cluster contains only five Spanish cultivars from miscellaneous origin: northeastern Spain (Trell and Marconeta), southwestern Spain (Cartayera), Majorca (Pou de Felanitx), and the Canary Islands (Liso).

The third group offers a more complex analysis due to the presence of cultivars from many different origins. Two 


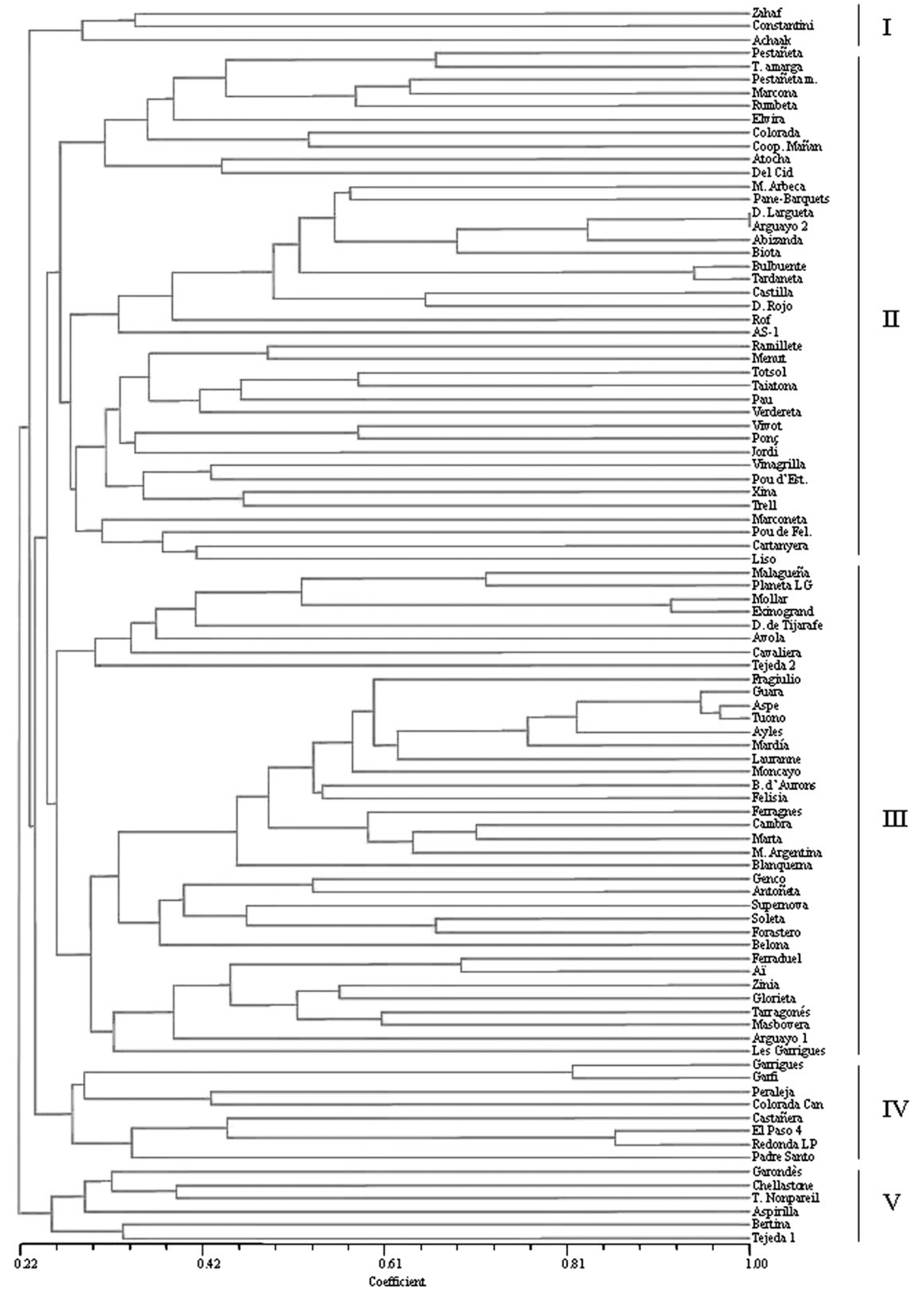

Fig. 1. Dendrogram of the 93 almond cultivars studied based on UPGMA analysis using the similarity matrix generated by the Nei and Li coefficients after amplification with 19 SSRs.

subgroups can be again defined. The first subgroup comprises five cultivars from different Spanish regions, such as Andalusia in the south (Malagueña), northeastern Spain (Planeta de les Garrigues and Mollar), and the Canary Islands (Dura de
Tijarafe and Tejeda-2), but also three foreign cultivars, one from Bulgaria (Exinograd) and the two cultivars from the island of Sicily (Avola and Cavaliera). The second subgroup contains the Italian cultivars from Puglia (Tuono, Genco, and Fragiulio), 
the French Aï and Belle d'Aurons, and all the releases from the different breeding programs derived from these cultivars. Additionally, some cultivars from many different origins are also included in this subgroup, such as Marcona de Argentina (Argentina), Forastero (southwestern Spain), Zinia and Les Garrigues (northeastern Spain), and Arguayo-1 (Canary Islands).

The fourth group only clustered eight Spanish cultivars, which can be subdivided in two subgroups, one with cultivars from southeastern Spain (Peraleja, Garrigues, and its seedling Garfi) and the other with cultivars from the Canary Islands (Colorada de Canarias, Castañera, El Paso-4, Redona de la Palma, and Padre Santo).

The fifth group clustered away from the other groups and only contains six cultivars from completely different origins and showing similarity indices lower than 0.4 . These six cultivars include four from different Spanish regions (Garondès from Majorca, Aspirilla from southeastern Spain, Bertina from northeastern Spain, and Tejeda-1 from the Canary Islands), but also two foreign cultivars, Tardy Nonpareil from California and Chellastone from Australia.

Following the observation by Grasselly and Crossa-Raynaud (1980) that the traditional almond growing resulted in the emergence of adapted land races associated with specific production areas, mainly for French and Italian local ecotypes, a definite grouping of the Spanish cultivars could be established according to their geographical origin. Some cultivars, however, were placed outside of the group of most of the cultivars of their regions. This fact could be due to movements of seeds and/or bud sticks from one region to the other, as it has been suggested in the past (Estelrich, 1907). In addition, the clustering of all the recent releases from the European breeding programs, having used as parents 'Tuono' and other cultivars from the same Italian region of Puglia, such as Cristomorto and Genco, corresponds to their genetic relationship.

Only one Californian cultivar was included in this analysis, Tardy Nonpareil. Although it has been suggested that the California cultivars originated from a pool of French cultivars (Kester et al., 1991), Tardy Nonpareil did not cluster with the French cultivars studied. 'Chellastone' from Australia was also placed in this cluster, but further approaches are needed to establish a more precise genetic relationship.

Synonymy and PARENTage analysis. A single case of identity for all markers was observed, that of 'Desmayo Largueta' and 'Arguayo-2'. The latter is an accession collected in La Palma island, Canary Islands, and was introduced into the collection under the name of the nearest village. When examined, it was morphologically similar to 'Desmayo Largueta', showing both accessions the same ratings with the IBPGR descriptors (Gülcan, 1985). Later, the two accessions were cross-pollinated, showing that they are cross-incompatible (data not shown). As these observations have been now confirmed by their genetic identity, it may be concluded that 'Arguayo-2' is not a different accession than 'Desmayo Largueta'. This cultivar was probably introduced in the past in the Canary Islands due to its low chilling requirements (Alonso et al., 2005) and adaptation to the subtropical climate of these islands, but without maintaining its original name.

Most accessions examined are traditional cultivars of unknown parentage, thus the parentage analysis was not an objective of this work. Some cases, however, have been considered because of previous reports in the bibliography. 'Belle d'Aurons' was probably introduced in the 19th century in France as a seedling of 'Aï' (Grasselly and Crossa-Raynaud, 1980). The results of their allele similarity do not rule out this hypothesis.

'Guara' is a cultivar of unknown origin (Felipe and Socias i Company, 1987). Although it has been sometimes reported as a clonal selection of 'Tuono', our results show that they are different, although close, accessions. The dendrogram (Fig. 1) shows that 'Tuono' is closer to another accession, 'Aspe', a named selection from the CITA breeding program obtained from self-pollination of 'Tuono'. The results show that 'Aspe' and 'Guara' could have originated by 'Tuono' self-pollination.

'Blanquerna' is an open-pollinated seedling of 'Genco' (Socias i Company and Felipe, 1999). The pollen parent is unknown, but the analysis of their SSR markers confirmed the 'Genco' parentage and suggested the possibility that the pollen parent was 'AS-1', a local selection from northeastern Spain (Kodad et al., 2009). 'AS-1' was located in the almond collection in the nearest row to 'Genco', thus pollen could be transferred from one row to the other, suggesting a possible confirmation of this hypothesis.

CONCLUDING REMARKs. The usefulness of SSR markers for cultivar identification in almond has been confirmed. The only case of identity of markers has coincided with an evident accession identity. The utilization of a wider spectrum of cultivars has also confirmed the large variability found among almond cultivars, as shown by the low coefficients of similarity between accessions from the same region. Some parentage relationships previously unknown could be established, widening the possibilities of application of SSR markers for germplasm and breeding management.

\section{Literature Cited}

Alonso, J.M., J.M. Ansón, M.T. Espiau, and R. Socias i Company. 2005. Determination of endodormancy break in almond flower buds by a correlation model using the average temperature of different day intervals and its application to the estimation of chill and heat requirements and blooming date. J. Amer. Soc. Hort. Sci. 130:308-318. Aranzana, M.J., A. Pineda, P. Cosson, E. Dirlewanger, J. Ascasibar, G. Cipriani, C. Ryder, R. Testolin, A. Abbott, G. King, A. Iezzoni, and P. Arús. 2003. A set of simple-sequence repeat (SSR) markers covering the Prunus genome. Theor. Appl. Genet. 106:819-825.

Aranzana, M.J., J. Garcia-Mas, J. Carbó, and P. Arús. 2002. Development and variability analysis of microsatellites markers in peach. Plant Breed. 121:87-92.

Arulsekar, S., D.E. Parfitt, and D.E. Kester. 1986. Comparison of isozyme variability in peach and almond cultivars. J. Hered. 77:272274.

Arús, P., T. Yamamoto, E. Dirlewanger, and A.G. Abbott. 2006. Synteny in the Rosaceae. Plant Breed. Rev. 27:175-211.

Bartolozzi, F., M.L. Warburton, S. Arulsekar, and T.M. Gradziel. 1998. Genetic characterization among California almond cultivars and breeding lines detected by randomly amplified polymorphic DNA (RAPD) analysis. J. Amer. Soc. Hort. Sci. 123:381-387.

Brookfield, J.F.Y. 1996. A simple new method for estimating null allele frequency from heterozygote deficiency. Mol. Ecol. 5:453455 .

Cantini, C., A.F. Iezzoni, W.F. Lamboy, M. Boritzki, and D. Struss. 2001. DNA fingerprinting of tetraploid cherry germplasm using simple sequence repeats. J. Amer. Soc. Hort. Sci. 126:205-209.

Cerezo, M., R. Socias i Company, and P. Arús. 1989. Identification of almond cultivars by pollen isoenzymes. J. Amer. Soc. Hort. Sci. 114: 164-169.

Cipriani, G., G. Lot, H.G. Huang, M.T. Marrazzo, E. Peterlunger, and R. Testolin. 1999. AC/GT and AG/CT microsatellite repeats in 
peach (Prunus persica (L.) Batsch): Isolation, characterization and cross-species amplification in Prunus. Theor. Appl. Genet. 99:65-72.

Clarke, J.B. and K.R. Tobutt. 2003. Development and characterization of polymorphic microsatellites from Prunus avium 'Napoleon'. Mol. Ecol. Notes 3:578-580.

Dirlewanger, E., P. Cosson, M. Travaud, M.J. Aranzana, C. Poizat, A. Zanetto, P. Arús, and F. Laigret. 2002. Development of microsatellite markers in peach [Prunus persica (L.) Batsch] and their use in genetic diversity analysis in peach and sweet cherry (Prunus avium L.). Theor. Appl. Genet. 105:127-138.

Downey, L.D. and A.F. Iezzoni. 2000. Polymorphic DNA markers in black cherry (Prunus serotina) are identified using sequences from sweet cherry, peach, and sour cherry. J. Amer. Soc. Hort. Sci. 125:76-80.

Doyle, J.J. and J.L. Doyle. 1987. A rapid DNA isolation procedure for small quantities of fresh leaf tissue. Phytochem. Bul. 19:11-15.

Espiau, M.T., J.M. Ansón, and R. Socias i Company. 2002. The almond germplasm bank of Zaragoza. Acta Hort. 591:275-278.

Estelrich, P. 1907. El almendro y su cultivo en el mediodía de España e Islas Baleares. Hijos de J. Cuesta/Antonio López, Madrid/Barcelona, Spain.

Felipe, A.J. 2000. El almendro. I. El material vegetal. Integrum, Lleida, Spain.

Felipe, A.J. 2002. Overlook on almond cultivars and rootstocks: A lifetime of experience. Acta Hort. 591:29-41.

Felipe, A.J. and R. Socias i Company. 1987. 'Aylés', 'Guara', and 'Moncayo' almonds. HortScience 22:961-962.

Grasselly, C. 1972. L'amandier: Caractères morphologiques et phsyiologiques des variétés, modalité de leurs transmissions chez les hybrides de première génération, Université Bordeaux, France. $\mathrm{Ph} . \mathrm{D}$. thesis.

Grasselly, C. 1976. Les espèces sauvages d'amandier. Options Méditerranéennes 32:28-43.

Grasselly, C. and P. Crossa-Raynaud. 1980. L'amandier. G.P. Maisonneuve et Larose, Paris.

Gülcan, R. 1985. Almond descriptors (revised). International Board for Plant Genetic Resources, Rome.

Gupta, P.K., H.S. Balyan, P.C. Sharma, and B. Ramesh. 1996. Microsatellites in plants: A new class of molecular markers. Curr. Sci. 70:45-54.

Hauagge, R., D.E. Kester, S. Arulsekar, D.E. Parfitt, and L. Liu. 1987. Isozyme variation among California almond cultivars. 2. Cultivar characterization and origins. J. Amer. Soc. Hort. Sci. 112:693-698.

Howad, W., T. Yamamoto, E. Dirlewanger, R. Testolin, P. Cosson, G. Cipriani, A.J. Monforte, L. Georgi, A.G. Abbott, and P. Arús. 2005. Mapping with a few plants: Using selective mapping for microsatellite saturation of the Prunus reference map. Genetics 171:13051309.

Hurtado, M.A., A. Westman, E. Beck, G.A. Abbott, G. Llácer, and M.L. Badenes. 2002. Genetic diversity in apricot cultivars based on AFLP markers. Euphytica 127:297-301.

Kester, D.E., T.M. Gradziel, and C. Grasselly. 1991. Almonds (Prunus). Acta Hort. 290:699-758.

Kodad, O., A.J. Felipe, A. Sánchez, M.M. Oliveira, and R. Socias i Company. 2009. Self-(in)compatibility in 'AS-1', a local Spanish almond cultivar. V Intl. Soc. Hort. Sci. Symp. on Pistachios and Almonds, Sanliurfa, Turkey.
Kodad, O., J.M. Alonso, A. Sánchez, M.M. Oliveira, and R. Socias i Company. 2008. Evaluation of genetic diversity of $S$-alleles in an almond germplasm collection. J. Hort. Sci. Biotechnol. 83:603608 .

Martínez-Gómez, P., S. Arulsekar, D. Potter, and T.M. Gradziel. 2003. An extended interspecific gene pool available to peach and almond breeding characterized using simple sequence repeat (SSR) markers. Euphytica 131:313-322.

Messeguer, R., P. Arús, and M. Carrera. 1987. Identification of peach cultivars with pollen isozymes. Scientia Hort. 31:107-117.

Mnejja, M., M. Garcia-Mas, W. Howad, M.L. Badenes, and P. Arús. 2004. Simple sequence repeat (SSR) markers of japanese plum (Prunus salicina Lindl.) are highly polymorphic and transferable to peach and almond. Mol. Ecol. Notes 4:163-166.

Mnejja, M., M. Garcia-Mas, W. Howad, M.L. Badenes, and P. Arús. 2005. Development and transportability across Prunus species of 42 polymorphic almond microsatellites. Mol. Ecol. Notes 5:531-535.

Nei, M. and W.H. Li. 1979. Mathematical model for studying genetic variation interms of restriction endonucleases. Proc. Natl. Acad. Sci. USA 76:5269-5273

Rikhter, A.A. 1972. Biological bases for the creation of almond cultivars and commercial orchards (in Russian). Editions Acad. Sci. Union Soviet Socialist Republics, Glavny Botanical Garden, Moscow, Russia.

Socias i Company, R. 1990. Breeding self-compatible almonds. Plant Breeding Rev. 8:313-338.

Socias i Company, R. 1998. Fruit tree genetics at a turning point: The almond example. Theor. Appl. Genet. 96:588-601.

Socias i Company, R. and A.J. Felipe. 1992. Almond: A diverse germplasm. HortScience 27:717-718, 803.

Socias i Company, R. and A.J. Felipe. 1999. 'Blanquerna', 'Cambra', y 'Felisia': Tres nuevos cultivares autógamos de almendro. Información Técnica Económica Agrararia 95V:111-117.

Spiegel-Roy, P. 1986. Domestication of fruit trees, p. 201-211. In: C. Barigozzi (ed.). The origin and domestication of cultivated plants. Elsevier, Amsterdam, The Netherlands.

Testolin, R., T. Marrazzo, G. Cipriani, R. Quarta, I. Verde, T. Dettori, M. Pancaldi, and S. Sansavini. 2000. Microsatellite DNA in peach (Prunus persica (L.) Batsch) and its use in fingerprinting and testing the genetic origin of cultivars. Genome 43:512-520.

de Vicente, M.C., M.J. Truco, J. Egea, L. Burgos, and P. Arús. 1998. RFLP variability in apricot (Prunus armeniaca L.). Plant Breed. 117:153-158.

Warburton, M.L. and F.A. Bliss. 1996. Genetic diversity in peach (Prunus persica (L.) Batsch) revealed by randomly amplified polymorphic DNA (RAPD) markers and compared to inbreeding coefficients. J. Amer. Soc. Hort. Sci. 121:1012-1019.

Wright, S. 1951. The genetical structure of populations. Ann. Eugen. 15:323-354.

Wu, S.B., M. Wirthensohn, P. Hunt, J.P. Gibson, and M. Sedgley. 2008. High resolution melting analysis of almond SNPs derived from ESTs. Theor. Appl. Genet. 118:1-14.

Xie, H., Y. Sui, F.Q. Chang, Y. Xu, and R.C. Ma. 2006. SSR allelic variation in almond (Prunus dulcis MIll.). Theor. Appl. Genet. $112: 366-372$. 